\title{
Various Mechanisms Cause RET-mediated Signaling Defects in Hirschsprung's Disease
}

\author{
Anna Pelet, ${ }^{\star}$ Olivier Geneste, ${ }^{\ddagger}$ Patrick Edery, ${ }^{\star}$ Andrea Pasini, ${ }^{\ddagger}$ Sophie Chappuis, ${ }^{\ddagger}$ Tania Attié, ${ }^{\star}$ Arnold Munnich, ${ }^{\star}$ \\ Gilbert Lenoir, ${ }^{\ddagger}$ Stanislas Lyonnet, ${ }^{*}$ and Marc Billaud ${ }^{\ddagger}$ \\ *Unité de Recherches sur les Handicaps Génétiques de l'Enfant INSERM U-393 et Département de Génétique, Hôpital Necker-Enfants \\ Malades, 75743, Paris Cedex 15, France; and ${ }^{\ddagger}$ Laboratoire de Génétique, CNRS UMR 5641, Domaine Rockefeller, 69373 Lyon Cedex \\ 08, France
}

\section{Abstract}

Hirschsprung's disease (HSCR) is a common congenital malformation characterized by the absence of intramural ganglion cells of the hindgut. Recently, mutations of the RET tyrosine kinase receptor have been identified in $\mathbf{5 0}$ and 15-20\% of familial and sporadic HSCR, respectively. These mutations include deletion, insertion, frameshift, nonsense, and missense mutations dispersed throughout the RET coding sequence. To investigate their effects on RET function, seven HSCR missense mutations were introduced into either a 1114-amino acid wild-type RET isoform (RET51) or a constitutively activated form of RET51 (RET-MEN 2A). Here, we report that one mutation affecting the extracytoplasmic cadherin domain $(\mathrm{R} 231 \mathrm{H})$ and two mutations located in the tyrosine kinase domain (K907E, E921K) impaired the biological activity of RET-MEN 2A when tested in Rat1 fibroblasts and pheochromocytoma PC12 cells. However, the mechanisms resulting in RET inactivation differed since the receptor bearing $\mathrm{R} 231 \mathrm{H}$ extracellular mutation resulted in an absent RET protein at the cell surface while the E921K mutation located within the catalytic domain abolished its enzymatic activity. In contrast, three mutations mapping into the intracytoplasmic domain neither modified the transforming capacity of RET-MEN 2A nor stimulated the catalytic activity of RET in our ligand-independent system (S767R, P1039L, M1064T). Finally, the C609W HSCR mutation exerts a dual effect on RET since it leads to a decrease of the receptor at the cell surface and converted RET51 into a constitutively activated kinase due to the formation of disulfide-linked homodimers. Taken together, our data show that allelic heterogeneity at the RET locus in HSCR is associated with various molecular mechanisms responsible for RET dysfunction. (J. Clin. Invest. 1998. 101:1415-1423.) Key words: RET • tyrosine kinase • Hirschsprung's disease $\bullet$ mutations $\bullet$ genetics

Address correspondence to Marc Billaud, Laboratoire de Génétique, CNRS UMR 5641, Domaine Rockefeller, 8, avenue Rockefeller, 69373 Lyon Cedex 08, France. Phone: 33-478-77-72-13; FAX: 33-47877-72-20; E-mail: billaud@univ-lyon1.fr Olivier Geneste's present address is Transcription Laboratory, Imperial Cancer Research Fund, 44 Lincoln's Inn Fields, London W2CA 3PX, United Kingdom.

Received for publication 10 April 1997 and accepted in revised form 7 January 1998.

J. Clin. Invest.

(C) The American Society for Clinical Investigation, Inc. 0021-9738/98/03/1415/09 \$2.00

Volume 101, Number 6, March 1998, 1415-1423

http://www.jci.org

\section{Introduction}

Hirschsprung's disease (HSCR, ${ }^{1}$ aganglionic megacolon) is a frequent congenital malformation (1/5,000 live births) responsible for intestinal obstruction in neonates, and characterized by the absence of parasympathetic intrinsic ganglion cells in the terminal hindgut (1). Since enteric neuroblasts are derived from neural crest cells, HSCR is regarded as a neurocristopathy $(2,3)$. According to segregation analysis suggesting incompletely penetrant dominant inheritance in long-segment HSCR (4), we and others have mapped a dominant gene for HSCR to chromosome 10q11.2 $(5,6)$ and ascribed the disease to heterozygous mutations of the $R E T$ protooncogene $(7,8)$ that encodes a tyrosine kinase receptor (9). Recently, it has been shown that RET is the signaling component of a multisubunit complex acting as a receptor for the glial cell line-derived neurotrophic factor (GDNF) (10-13) and neurturin (14) two neurotrophic factors related to the TGF- $\beta$ family, both requiring GPI-linked glycoprotein coreceptors to allow RET dimerization (GDNFR $\alpha$ and GDNFR $\beta$ ) (15). Germline mutations of RET are also responsible for multiple endocrine neoplasia type 2 (MEN 2), a group of dominantly inherited cancer syndromes (for reviews see references 16-18). MEN 2 mutations are missense mutations located in the cysteine-rich region of the extracellular domain of RET and cause the replacement of one of five clustered cysteines by a different amino acid (MEN 2A) or within the catalytic tyrosine kinase domain (MEN 2B) (19).

Recently, we and others have demonstrated that MEN 2A mutations convert the RET protooncogene in a dominantly acting transforming gene due to covalent dimerization of RET monomers via disulfide bond, resulting in ligand-independent constitutive activation of the tyrosine kinase (20-23). Conversely, several lines of evidence support the view that HSCR mutations are inactivating and cause the loss of RET function, namely: $(a)$ the nature of mutations which include both truncation and missense mutations scattered throughout the RET gene coding sequence (24); (b) the ability of HSCR missense mutations to abolish the transforming effects of oncogenic forms of RET (25-27); and (c) the targeted homozygous disruption of RET that results in intestinal aganglionosis in mice (28). However, some observations are difficult to reconcile with a loss of function model such as the cosegregation of MEN 2A and HSCR in several families (29). To better understand the molecular mechanisms underlying RET dysfunction, we have analyzed the biological consequences of seven inde-

1. Abbreviations used in this paper: GDNF, glial cell line-derived neurotrophic factor; HRP, horseradish peroxidase; HSCR, Hirschsprung's disease; MBP, myelin basic protein; MEN, multiple endocrine neoplasia. 
pendent HSCR mutations. Here we report that three HSCR mutations inhibited the biological action of a constitutively active form of RET while one mutation transformed the RET gene into an oncogene. Finally, three HSCR mutations had no detectable effect on RET function in our system. Thus, we demonstrate that RET dysfunction in HSCR could be ascribed to various mechanisms depending on the location of missense mutation in the RET protein.

\section{Methods}

Site-directed mutagenesis and production of ecotropic retroviruses. The cDNA coding for the 1,114-amino acid isoform of human RET (RET51) was cloned into the pBabe Puro retroviral vector $(23,30)$. HSCR mutations were introduced by site-directed mutagenesis (Unique Site Elimination Mutagenesis kit; Pharmacia Biotech, Piscataway, $\mathrm{NJ})$ with the following primers: R231H: 5'-CTGGGCCCTGGACCACGAGCAGCGGGAGAAGTACG-3'; C609W: 5'-GGCTATGGCACCTGGAACTGCTTCCCT-3'; S767R: 5'-GAACGCCTCCCCGAGGGAGCTTCGAGACCTG-3'; K907E: 5'-GAGGATTCCTACGTGGAGAGGAGCCAGGGTC-3'; E921K: 5'-GTTAAATGGATGGCAATTAAATCCCTTTTTGATCAT-3'; P1039L: 5'-GAGGAGGAGACACTGCTGGTGGACTGT-3'; M1064T: 5'-CAAACTCTATGGCACGTCAGACCCGAAC-3'. Each mutation was confirmed by DNA sequencing on both strands. Ecotropic retroviruses were obtained by transient transfection of the pBabe Puro retroviral vectors into the BOSC 23 packaging cell line according to the protocol described by Pear et al. (31). Titrations of the virus supernatants and infections were performed as described previously (23).

Anchorage-independent growth of Rat1 cells. Retroviral infected Rat1 cells were mass-selected with puromycin and seeded into culture medium containing $10 \%$ FCS and $0.3 \%$ agar as described in Rossel et al. (23). Colonies were counted 3 wk after plating.

Effects of the expression of mutant RET proteins in PC12 cells. PC12 cells were maintained in DME supplemented with glucose (4.5 g/liter), 6\% horse serum (Sigma Chemical Co., St. Louis, MO), 6\% FCS, and antibiotics (32). PC12 cells were plated at $3 \times 10^{5}$ cells per $60-\mathrm{mm}$ culture dish. The day after plating, cells were incubated with $10^{6}$ infectious particles in $3 \mathrm{ml}$ of the culture medium containing $8 \mu \mathrm{g} / \mathrm{ml}$ of polybrene. $7 \mathrm{~h}$ after infection, the medium was removed and replaced by fresh medium. Micrographs were taken $4 \mathrm{~d}$ after infection.

RET protein studies. The antiserum anti-RET was raised against a peptide corresponding to the 20 amino acids of the carboxy-terminal part of the short RET isoform (prepared by Biocytex, Marseille, France). This antibody reacts with both the short (RET9) and long RET (RET51) isoforms (23). Other antibodies used in this study are commercially available: the monoclonal antiphosphotyrosine 4G10 and the rabbit polyclonal anti-Shc were purchased from Upstate Biotechnology Inc. (Lake Placid, NY) and Transduction Laboratories (Lexington, KY), respectively. RET protein analyses were performed as described by Rossel et al. (23).

Immunokinase assay and studies of the RET covalent dimer. Mass-selected NIH 3 T3 cells stably expressing mutant RET proteins were rinsed with PBS, scraped into $1 \mathrm{ml}$ of lysis buffer $(20 \mathrm{mM}$ Tris$\mathrm{HCl}, \mathrm{pH} 7.8,150 \mathrm{mM} \mathrm{NaCl}, 1 \mathrm{mM}$ sodium orthovanadate, $1 \%$ Nonidet P-40, $1 \mathrm{mM}$ PMSF, $10 \mu \mathrm{g} / \mathrm{ml}$ aprotinin, $10 \mu \mathrm{g} / \mathrm{ml}$ leupeptin and $2 \mathrm{mM}$ EDTA), and incubated on ice for $15 \mathrm{~min}$. Lysates were precleared with the rabbit preimmune serum, then subjected to immunoprecipitation with the anti-RET serum. Immune complexes were absorbed on protein A coupled to Sepharose beads (protein A-Sepharose CL4B; Pharmacia Biotech) and successively washed twice in immunoprecipitation buffer and twice in immunokinase assay buffer (50 $\mathrm{mM}$ Hepes, $\mathrm{pH}$ 7.2, $5 \mathrm{mM} \mathrm{MnCl}_{2}, 1 \mathrm{mM}$ PMSF). The immunoprecipitates were then incubated for $20 \mathrm{~min}$ at room temperature in $30 \mu \mathrm{l}$ of immunokinase buffer containing $4 \mu \mathrm{Ci}$ of $\left[\gamma^{-32} \mathrm{P}\right] \mathrm{ATP}(5,000 \mathrm{Ci} /$ mmol; ICN Biomedicals Inc., Irvine, CA) diluted with unlabeled ATP to a final concentration of $26 \mathrm{pmol}$ with $7 \mu \mathrm{M}$ myelin basic pro- tein (MBP). The reaction was stopped by addition of Laemmli buffer (20 mM Tris-HCl, pH 6.8, 2 mM EDTA, 2\% SDS, 20\% glycerol, and $20 \mu \mathrm{g} / \mathrm{ml}$ of bromophenol blue) in the presence of $1.4 \mathrm{M}$ of 2-mercaptoethanol. Proteins were boiled 3 min, then loaded on a $15 \%$ SDS polyacrylamide gel. ${ }^{32} \mathrm{P}$-labeled bands were revealed by autoradiography of the dried gel and quantified on an imaging densitometer (model GS 670; Bio-Rad Laboratories, Richmond, CA). To detect the disulfide-linked RET homodimer, the same immunokinase assay protocol was used, except that 2-mercaptoethanol was omitted at the last step. Proteins were boiled 3 min and separated on a 6\% SDS polyacrylamide gel.

Biotin labeling of cell surface proteins. NIH3T3 cells stably expressing mutant RET proteins were washed with biotinylation buffer (10 mM Hepes, $\mathrm{pH} 8.8,150 \mathrm{mM} \mathrm{NaCl}$ ) then biotin (Biosys, Compiègne, France) was added to a final concentration of $150 \mu \mathrm{g} / \mathrm{ml}$ of biotinylation buffer and incubated $15 \mathrm{~min}$ at $20^{\circ} \mathrm{C}$. The biotinylation reaction was stopped by the addition of Tris- $\mathrm{HCl}, \mathrm{pH} 7.4$, to a final concentration of $50 \mathrm{mM}$. Cells were washed with $10 \mathrm{mM}$ Tris- $\mathrm{HCl}, \mathrm{pH}$ 7.4, containing $150 \mathrm{mM} \mathrm{NaCl}(21,26)$. Cell pellets were precipitated by streptavidin agarose (20347; Pierce Chemical Co., Rockford, IL) and analyzed on an $8 \%$ SDS-PAGE gel.

Analysis of Shc phosphorylation. NIH3T3 cells stably expressing the various RET alleles were starved overnight in medium containing $0.5 \%$ of FBS and then lysed as described previously (23). Shc proteins were immunoprecipitated with a polyclonal anti-Shc antibody (Transduction Laboratories). Immunoprecipitates were subjected to $12 \%$ SDS-PAGE and transferred to a polyvinylidene difluoride membrane (Immobilon P; Millipore Corp., Bedford MA). To analyze the phosphotyrosine content of Shc, immunoblots were incubated with the antiphosphotyrosine monoclonal antibody 4G10 (Upstate Biotechnology Inc.), then incubated with anti-mouse antibody conjugated to horseradish peroxidase (HRP) (Amersham France, Les Ulis, France). The immunoreactive complexes were visualized using chemiluminescence (ECL Western blotting system; Amersham France). The membranes were then stripped by incubation in stripping buffer (100 mM 2-mercaptoethanol, 2\% SDS, $62.5 \mathrm{mM}$ Tris-HCl, $\mathrm{pH} 6.8$ ) and treated at $55^{\circ} \mathrm{C}$ for $30 \mathrm{~min}$. To study the Shc proteins, the filters were sequentially reacted with the polyclonal anti-Shc serum (Transduction Laboratories) for $2 \mathrm{~h}$ at room temperature, then with biotinylated protein A (Amersham France) for $1 \mathrm{~h}$ and finally with HRP conjugated to streptavidin (Pierce, Interchim, France) for $1 \mathrm{~h}$. The ECL system was used for the revelation of immunoreactive bands. $2 \mu \mathrm{g}$ of Shc antibody was used for each immunoprecipitation experiment and the same serum was diluted at a final concentration of $1 \mu \mathrm{g} /$ $\mathrm{ml}$ for Western blot; biotinylated protein A was diluted 1:500; streptavidin-HRP was used at a final concentration of $1 \mu \mathrm{g} / \mathrm{ml}$.

\section{Results}

Six HSCR mutations were introduced into a cDNA encoding a constitutively activated MEN 2A mutant form of RET (RET51-C634R, Fig. 1). The C609W HSCR mutation leads to the replacement of a cysteine involved in MEN 2A (19). This mutation was likely to result in RET activation and thus was introduced into the RET51 wild-type cDNA.

Consequences of HSCR mutations on RET-induced biological effects. To investigate the biological effects of HSCR mutations, we assessed the anchorage-independent growth capacity of Rat 1 cells stably expressing various RET mutants. 3 wk after seeding in soft agar, Rat1 cells expressing RET-634R containing mutations S767R, P1039L, and L1064T gave rise to colonies (Table I). Conversely, the R231H, HSCR mutant significantly reduced the number of colonies in transduced RAT1 cells, and mutations K907E and E921K produced a number of colonies not significantly different from the background levels observed with the wild-type RET control (Table I). Since mu- 


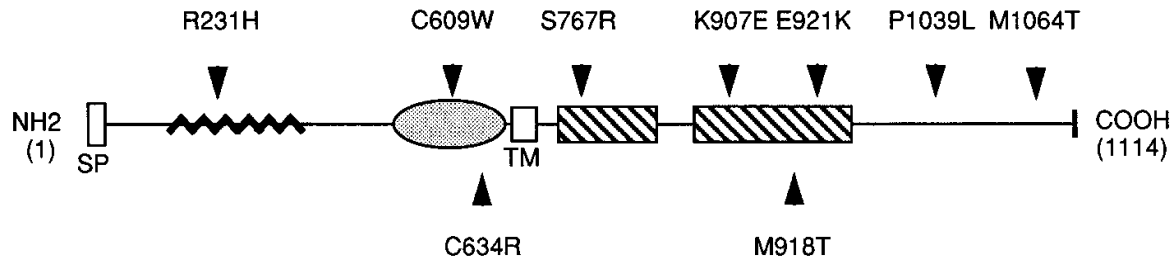

Figure 1. Schematic representation of the HSCR mutations introduced into RET wild-type or RET-MEN 2A. (Top) HSCR missense mutations analyzed in this study. (Bottom) The RET-MEN 2A mutant C634R was used as a constitutively activated form of RET. The various domains of the RET protein are indicated: $S P$, signal peptide; wavy line, cadherin-domain; shaded oval, cysteine-rich domain; TM, transmembrane domain; striped box, tyrosine kinase domain. tations S767R, P1039L, and M1064T did not substantially modify the transforming capacity of RET-634R, we could not formally exclude that they might be activating. To address this question, these mutations were introduced in RET wild-type. Rat1 cells transduced with retroviruses expressing these mutants did not produce colonies in agar (data not shown). Finally, HSCR mutation C609W on a wild-type RET background gave rise to RAT1 cell colonies, although the transforming effect was weaker than the one observed with RET634R (Table I).

Previous reports have shown that the expression of MEN 2 forms of RET is transforming in rodent fibroblasts and induces neuronal differentiation of rat pheochromocytoma PC12 cells (20-23). PC12 cells infected with retroviruses expressing RET634/767R, RET-634R/1039L, RET-634R/1064T, and RET609W elaborated neurites and displayed morphological changes similar to those observed with RET-634R. On the contrary, PC12 cells expressing RET-634R with HSCR mutations $\mathrm{R} 231 \mathrm{H}, \mathrm{K} 907 \mathrm{E}$, and $\mathrm{E} 921 \mathrm{~K}$ did not show any phenotypic change as compared with PC12 cells expressing wild-type RET (Fig. 2).

These results indicate that several HSCR mutations abolish (K907E and $\mathrm{E} 921 \mathrm{~K})$ or dramatically reduce $(\mathrm{R} 231 \mathrm{H})$ the biological activity of RET-634R, whereas HSCR mutations S767R, P1039L, and M1064T did not substantially modify the capacity of RET-634R to transform fibroblasts and to induce neuronal differentiation of PC12 cells. Finally, the RET-609W HSCR mutant exhibited the same transforming and neural differentiation abilities as the RET MEN 2 mutants, although to a weaker extent.

Biochemical analyses of RET HSCR mutants. To address the effects of HSCR mutations on RET intrinsic kinase activity, the mutant RET proteins were immunoprecipitated and analyzed by Western blot technique. As previously described, two immunoreactive bands migrating at 150 and $170 \mathrm{kD}$ were detected. These two RET species are assumed to correspond to an incompletely glycosylated RET product present in the endoplasmic reticulum $(150 \mathrm{kD})$ and to the fully glycosylated protein expressed at the plasma membrane $(170 \mathrm{kD})(21,33)$. Fig. 3 shows that the amount of $170-\mathrm{kD}$ RET isoform is decreased in cells expressing RET-609W and RET-634R/231H as compared with cell lines expressing wild-type RET or other RET mutants. Conversely, the level of the $150-\mathrm{kD}$ product is markedly increased in cell lines expressing RET-609W and RET-634R/231H (Fig. $3 \mathrm{~A}$ ). To test the catalytic activity of RET HSCR mutants, we measured the level of steady-state phosphorylation on tyrosine residues. In accordance with previous reports, the RET-634R mutant showed a significant increase of phosphotyrosine content (20-23). Three RET HSCR mutants were not phosphorylated (RET-609W, RET-634R/ 231H, and RET-634R/921K, Fig. 3 B). Conversely, RET-634R protein carrying each of the four HSCR mutants K907E, S767R, 1039L, and M1064T was phosphorylated on tyrosine, although at a reduced level for the three latter mutants. Finally, mutations S767R, P1039L, and M1064T did not activate the RET wild-type catalytic activity (Fig. 3 B).

We next examined the catalytic activity of HSCR mutants with an immunocomplex-kinase assay using the MBP as an exogenous substrate (Fig. 4). Quantification of the reactive bands showed that the level of MBP phosphorylation correlated to RET autophosphorylation allowing further classification of the kinase activity of the various RET mutants (RET-634R;

Table I. Transformation Effects of RET51 Wild-Type and Mutant Protein on RAT1 Cell Lines

\begin{tabular}{|c|c|c|c|c|c|c|c|c|c|}
\hline & WT & $634 \mathrm{R}$ & $634 \mathrm{R} / 231 \mathrm{H}$ & $609 \mathrm{~W}$ & $634 \mathrm{R} / 767 \mathrm{R}$ & $634 \mathrm{R} / 907 \mathrm{E}$ & $634 \mathrm{R} / 921 \mathrm{~K} *$ & $634 \mathrm{R} / 1039 \mathrm{~L}$ & $634 \mathrm{R} / 1064 \mathrm{~T}$ \\
\hline \multirow[t]{4}{*}{ First assay } & $<3$ & 113 & 41 & 40 & 130 & 6 & 3 & 100 & \\
\hline & $<3$ & 100 & 50 & 62 & 100 & 19 & 10 & 130 & ND \\
\hline & $<3$ & 110 & 52 & 60 & 112 & 26 & 3 & & \\
\hline & & & $P<10^{-9}$ & $P<10^{-9}$ & NS & $P<10^{-9}$ & $P<10^{-3}$ & NS & \\
\hline \multirow[t]{4}{*}{ Second assay } & $<3$ & 130 & 25 & 45 & 180 & 7 & 4 & 207 & 134 \\
\hline & $<3$ & 130 & 29 & 67 & 175 & 11 & 2 & 180 & 113 \\
\hline & $<3$ & 170 & 55 & 59 & 165 & 8 & 2 & & 110 \\
\hline & & & $P<10^{-9}$ & $P<10^{-8}$ & $P<0.04$ & $P<10^{-3}$ & $P<10^{-3}$ & $P<10^{-2}$ & NS \\
\hline
\end{tabular}

Two independent infection assays were carried out on $10^{3}$ RAT1 cells. Foci were scored 3 wk after plating. The number of foci is indicated for each plate. $N D$, Not determined. A $\chi^{2}$ test was performed. *Student's $t$ test was performed due to the very low number of colonies. 

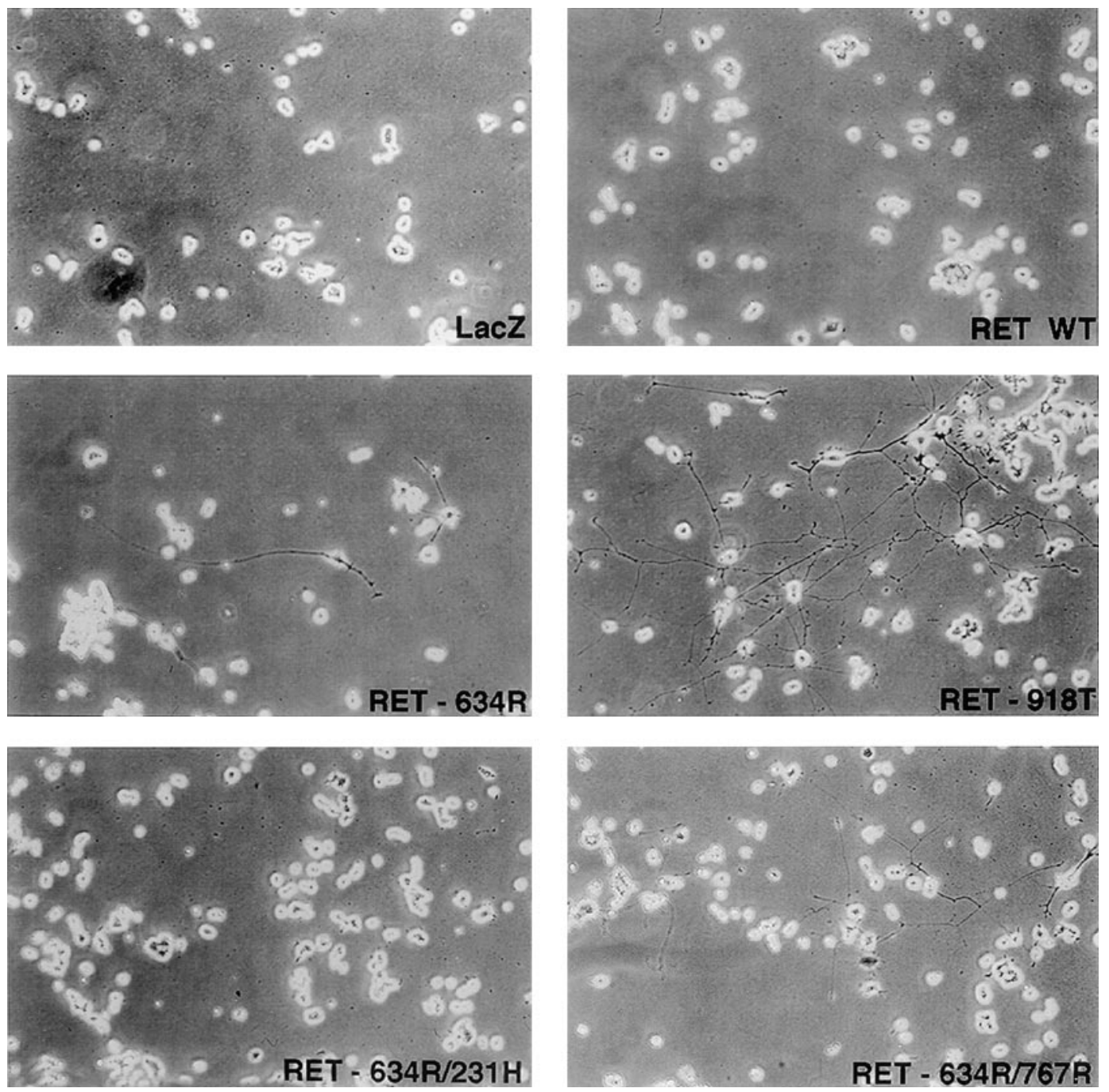

Figure 2. Effects of RET carrying HSCR mutations on PC12 cell morphology. The PC12 pheochromocytoma cell line was infected with retroviruses expressing normal RET51 (RET WT), mutant RET alleles, and control (RET51/634R, RET-918T, and LacZ NIH3T3 expressing $\beta$ galactosidase). Micrographs were taken $4 \mathrm{~d}$ after infection. Neuronal differentiation was observed for RET-609W, RET-634R/767R, RET634R/1039L, and RET634R/1064T.
RET-609W > RET-634R/767R; RET-634R/907E; RET634R/1064T $>$ RET-634R/1039L $>$ RET-634R/231H $>$ RETWT $>>$ RET-634R/921K). These results are consistent with the analysis of the steady-state phosphorylation of RET HSCR mutants, although it should be noted that the immunokinase assay allowed detection of a clear increase of RET609W kinase activity.

We then studied the tyrosine phosphorylation of Shc, a transduction protein that bridges receptor tyrosine kinases to the Ras-mitogen activated protein kinase pathway (34) and that has been shown to be phosphorylated by MEN 2 forms of RET (35-37). Fig. 5 shows that equivalent amounts of the three Shc isoforms were present in each lane (46, 52, and $66 \mathrm{kD})$. However, the phosphotyrosine content of $\mathrm{p} 52^{\mathrm{Shc}}, \mathrm{p} 46^{\mathrm{Shc}}$ and, to a lesser extent, of p66 ${ }^{\text {Shc }}$ was markedly increased in NIH3T3 cells expressing RET-609W as well as RET-634R carrying HSCR mutations S767R, K907E, P1039L, and M1064T. Conversely, the tyrosine phosphorylation of Shc was comparable to that of RET wild type in cell lines expressing RET-634R/231H or RET-634R/921K (Fig. 5). Therefore, both sets of data indicate that two RET HSCR mutants inactivate RET-634R catalytic functions (R231H, E921K), while the C609W leads to RET ac- tivation. The last four HSCR mutants do not significantly impair RET, MBP, or Shc phosphorylation.

HSCR mutations affecting the extracytoplasmic domain result in a reduced level of RET protein expressed at the cell surface. The reduction of the $170-\mathrm{kD}$ RET product observed in NIH3T3 cells expressing RET-634R/231H or RET-609W suggested that inhibition of RET transport to the cell surface might account for the disease-causing effects of HSCR mutation (Fig. 6). To test this hypothesis, NIH3T3 cells expressing equal amounts of RET protein were biotinylated in vivo. Western blot analysis shown in Fig. $6 \mathrm{~A}$ revealed that the RET-634R/231H and RET-609W 170-kD isoforms were dramatically reduced at the cell surface. Fig. $6 B$ shows that RET wild-type proteins bearing mutation affecting the intracytoplasmic domain (S767R, P1039L, M1064T, as well as RET51634R/907E and RET-634R/921K) were readily detected at the plasma membrane, thus supporting the view that HSCR mutations located in the extracytoplasmic domain decrease the amount of mature receptor present at the cell surface.

HSCR mutation C609W has a dual effect on RET. To investigate whether the C609W HSCR mutation might result in RET dimerization, we performed an immunocomplex kinase 

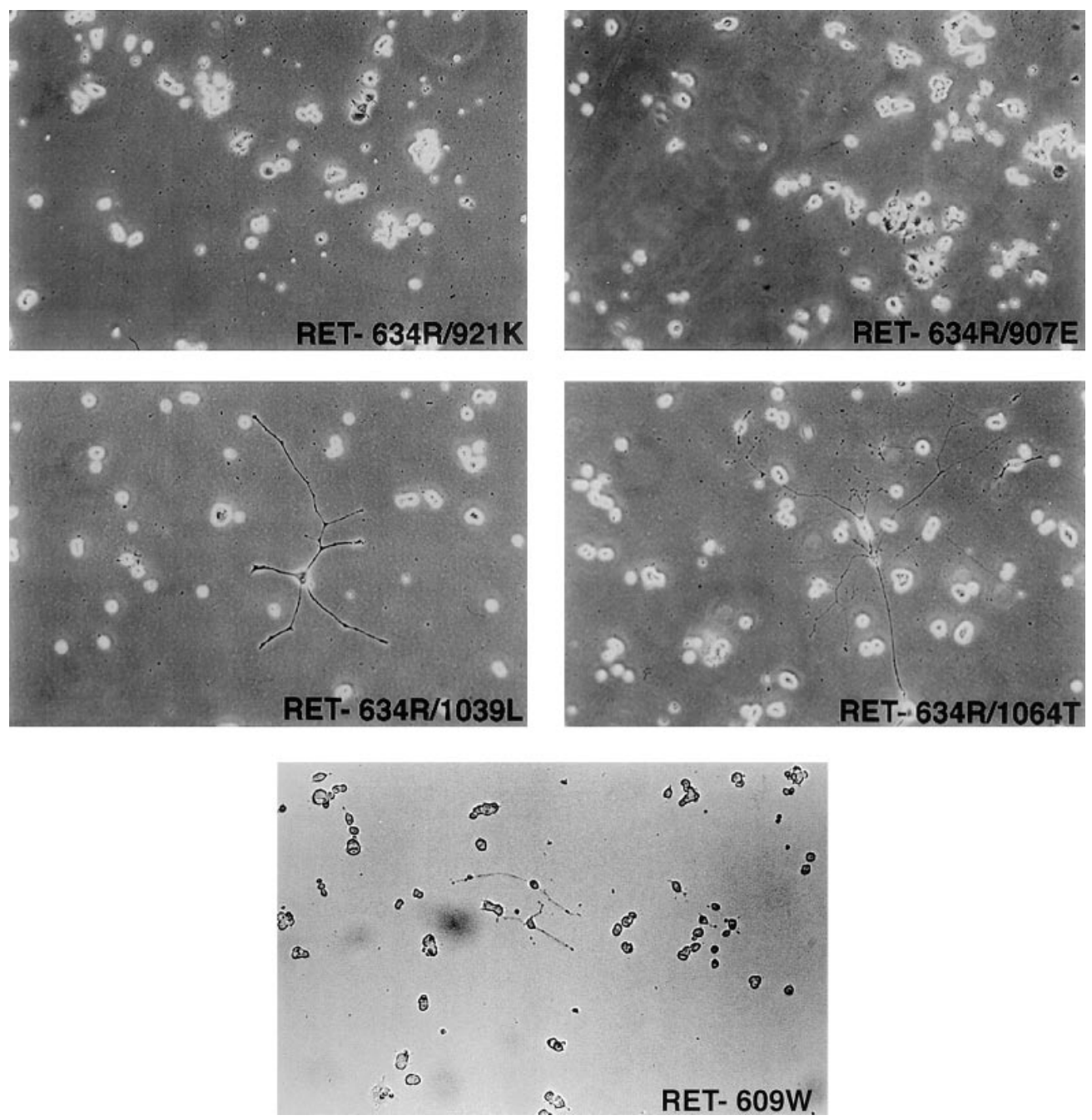

Figure 2 (Continued)

assay. The $340-\mathrm{kD}$ product corresponding to RET homodimer and specific to RET MEN 2 mutants carrying a cysteine mutation was detected in NIH3T3 cells expressing RET-609W and RET-634R (Fig. 7). Together with the results showed in Fig. 6 $A$, these findings support the view that the C609W HSCR mutation exerts a dual effect on RET resulting in both a reduced expression at the cell surface and the formation of a covalent dimer.

\section{Discussion}

Recent work has suggested that HSCR point mutations in the RET gene are invariably inactivating mutations although through distinct molecular mechanisms (25-27). In this report, we have investigated the effects of seven distinct HSCR missense mutations on RET function. Three mutations were selected owing to their location in the RET protein, namely, the cadherin-like domain $(\mathrm{R} 231 \mathrm{H})$, the cysteine-rich motif at a cysteine codon involved in MEN 2A (C609W), and the carboxy-terminal region specific for the long RET isoform (M1064T). Four mutations were chosen based on the phenotype of HSCR patients including the length of the aganglionic segment (total colonic aganglionosis for mutations S767R and $\mathrm{E} 921 \mathrm{~K}$ ) and the associated malformations (unilateral renal agenesis and congenital central hypoventilation syndrome for mutation K907E and P1039L, respectively). This study has revealed that three mutations disrupted the biological activity of the MEN 2A form of RET (R231H, K907E, E921K), while one mutation resulted in the oncogenic activation of RET due to the constitutive stimulation of the tyrosine kinase (C609W). Finally, in our system three HSCR mutations did not significantly change the biological effects mediated by RET-MEN 2A (S767R, P1039L, M1064T).

Arginine 231 is located in the RET cadherin domain. It is one of the four residues of the motif Leu-Asp-Arg-Glu (LDRE) that is highly conserved in most cadherins and forms one of the loops involved in calcium-binding $(38,39)$. However, while the RET cadherin domain can be superimposed to the amino-terminal cadherin domains of E-cadherin (Legrand, P., and M. Billaud, unpublished results) its function is not yet defined, especially as RET does not display clear $\mathrm{Ca}^{2+}$-dependent homophilic adhesive properties (40). The substitution of arginine 231 for histidine leads to a drastic reduction of the mutant RET protein present at the cell surface. Similarly, mu- 


\section{IP : $\alpha$ RET}

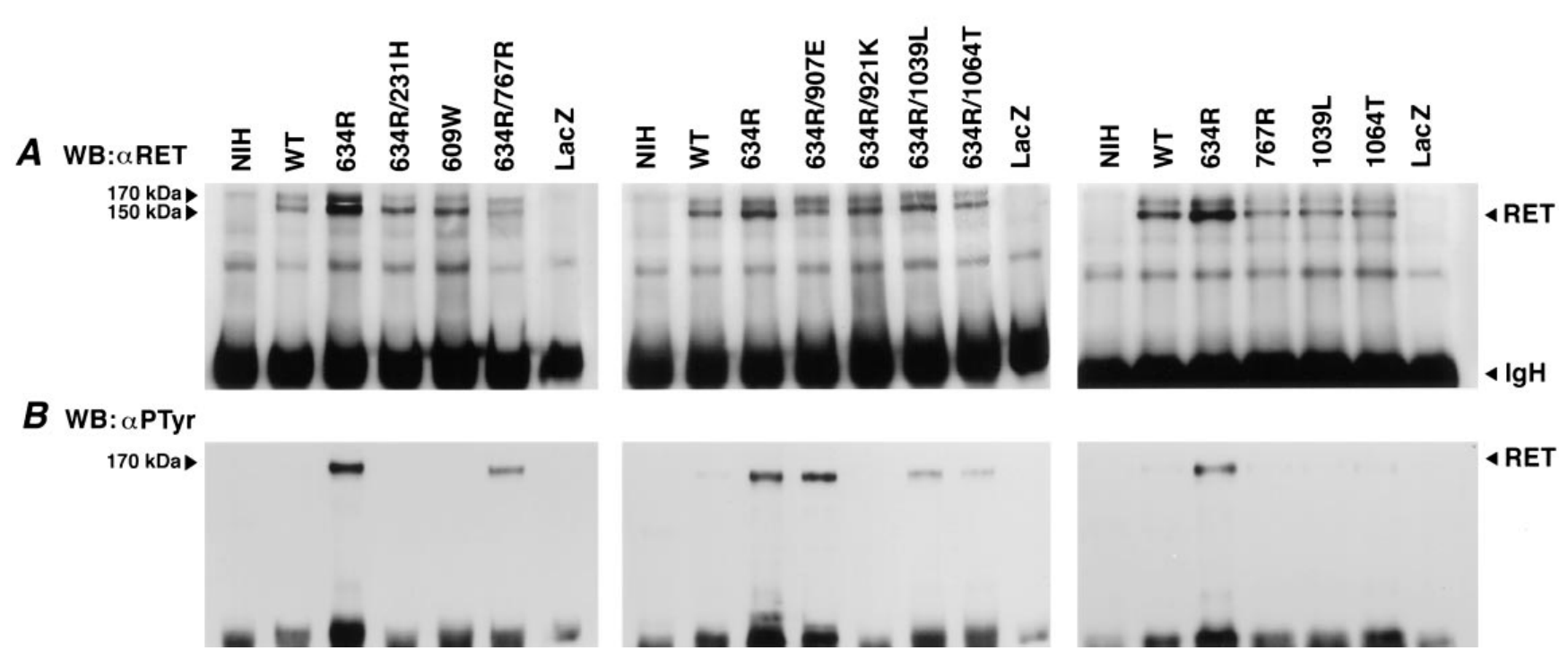

Figure 3. Expression and tyrosine phosphorylation of mutant RET proteins. Comparable amounts of RET proteins were immunoprecipitated from mass populations of puromycin-resistant NIH3T3 cells expressing the various RET mutants. Controls were NIH, RETWT, RET-634R, and LacZ. (A) RET monomer detection. Samples were fractionated on an $8 \%$ SDS polyacrylamide gel and analyzed by Western blotting with an anti-RET polyclonal serum. The two RET species of 170 and $150 \mathrm{kD}$ are indicated. (B) Tyrosine phosphorylation of RET. Western blots were reprobed with the monoclonal antiphosphotyrosine antibody $4 \mathrm{G} 10$. The $170-\mathrm{kD}$ phosphorylated band was absent for three constructions, namely RET-634R/231H, RET-609W, and RET-634R/921K and was decreased for RET-634R/1039L and the RET-634R/1064T.

tations of either codon Asp 264 (D264K) or Asp 300 (D300K) which are part of the putative $\mathrm{Ca}^{2+}$-binding site of the RET cadherin domain, and mutation of arginine 287 (R287Q) which is also located in the cadherin domain resulted in the intracel-

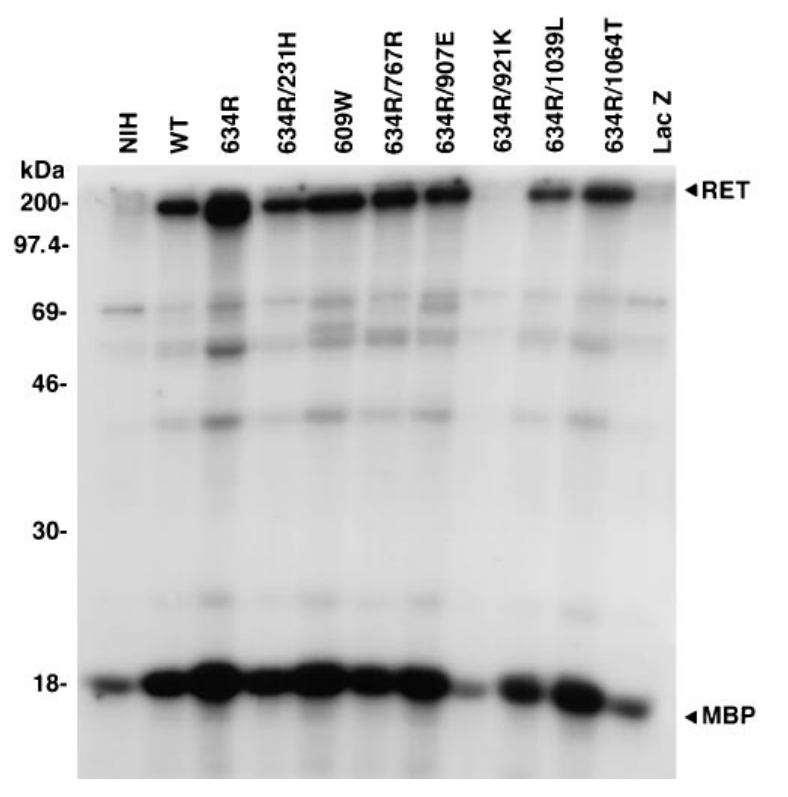

Figure 4. Immunocomplex kinase assay. Equal amounts of RET proteins were immunoprecipitated from lysates of NIH3T3 cells stably expressing various RET mutants. The immunocomplexes were subjected to an in vitro kinase assay using MBP as an exogenous substrate. Bands corresponding to autophosphorylated RET and to phosphorylated MBP are indicated. lular accumulation of the immature $150-\mathrm{kD}$ product (21) (Chappuis, S., and M. Billaud, unpublished results). Other HSCR mutations affecting the extracytoplasmic domain, outside the cadherin domain, have the same disruptive effect as mutation R231H. Thus, these data therefore support the idea that most extracellular missense mutations of RET might alter the protein folding and cause inappropriate intracellular trafficking $(26,27)$.

Among HSCR mutations located in the RET tyrosine kinase domain tested in this study, two out of three inhibited the biological activity of the MEN 2A form of RET (K907E, E921K). Although the functional consequences of each mutation were the same, biochemical analyses suggested that the underlying molecular mechanisms were different. Mutation K907E did not abrogate the tyrosine kinase activity of RETMEN 2A since this mutant was still able to efficiently phosphorylate substrates such as MBP and Shc. These results indicate that the K907E mutation might interfere with one of the RET-signaling pathways required for mitogenesis. Since Lys 907 is located in the close vicinity of Tyr 905 (41), a residue whose autophosphorylation creates a putative docking site for Grb10 and possibly Grb7, it is tempting to speculate that the K907E mutation might uncouple Grb7 and/or Grb10 from RET, thus dampening down the RET signal (27, 42-44). The negative effect of mutation E921K on RET-MEN 2A enzymatic activity implies that Glu 921, an amino acid strictly conserved in all serine/threonine and tyrosine kinases identified thus far, participates in the folding of the RET kinase domain (45). Similarly, three other HSCR mutations located in the tyrosine kinase domain have been shown to abolish or decrease the kinase activity of oncogenic forms of RET (25).

The RET C609W mutation occurred in an HSCR family 


\section{IP: $\alpha$ Shc}

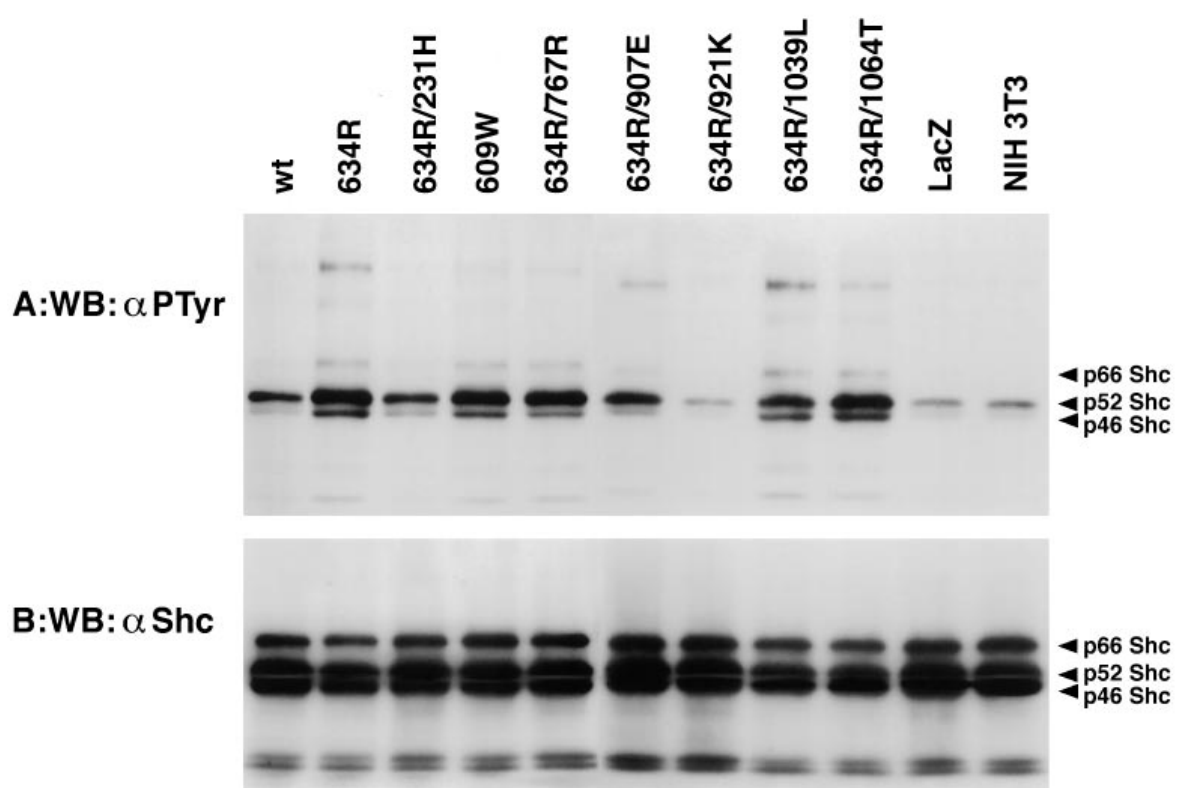

Figure 5. Tyrosine phosphorylation of Shc by RET mutants. Retroviral infected NIH3T3 cells stably expressing the various RET mutants were starved overnight in $0.5 \%$ FBS and then whole cell lysates were prepared. $(A)$ Shc proteins were immunoprecipitated with a rabbit polyclonal antiShc antibody (Transduction Laboratories) and the resultant immunoprecipitates were subjected to Western blot analysis using a monoclonal antiphosphotyrosine antibody (4G10; Upstate Biotechnology Inc.). (B) Filters were reprobed with the anti-Shc antibody; the three Shc isoforms of 66,52 , and $46 \mathrm{kD}$ are indicated. without any clinical manifestation involving either thyroid or adrenals (24) while other missense mutations at codon 609 have been identified in $8 \%$ of MEN 2A (19). Thus, it appeared likely that the replacement of cysteine 609 by a tryptophan exerted a disruptive effect on RET. Yet, the C609W mutation was found to cause RET covalent dimerization similar to the one observed with MEN 2A cysteine mutations. However, the amount of the mature $170-\mathrm{kD}$ form of RET present at the cell membrane was significantly decreased as compared with RET wild type or RET-634R, thereby indicating that mutation C609W also impaired the RET maturation. Consequently, the transforming capacity of RET-609W was approximately twofold less than the one displayed by RET634R. It is thus tantalizing to hypothesize that the weak level of the RET dimer cannot compensate for the marked decrease of RET at the plasma membrane of enteric neuroblasts result- ing in the HSCR phenotype. We cannot exclude the possibility that the covalent dimerization of RET- $609 \mathrm{~W}$ requires the overexpression of RET, the same as achieved in NIH3T3 cells and that, under physiological conditions, the dimer is not formed in enteric neuroblasts. Along the same lines, it is worth noting that two mutations, previously reported in MEN 2A patients have been identified in HSCR patients without evidence of MEN 2 phenotype (C609Y, C620R) (46). Finally, the same dual impact (the formation of disulfide-bound RET homodimer and inhibition of RET maturation) (47) might explain the occurrence of both HSCR and MEN 2A in rare families with RET mutation at codons 618 or 620.

Finally, three HSCR mutations did not substantially modify the biological activity of RET-MEN 2A in our systems (S767R, P1039L, M1064T). Mutation S767R was found in a sporadic case, while the two other mutations were inherited

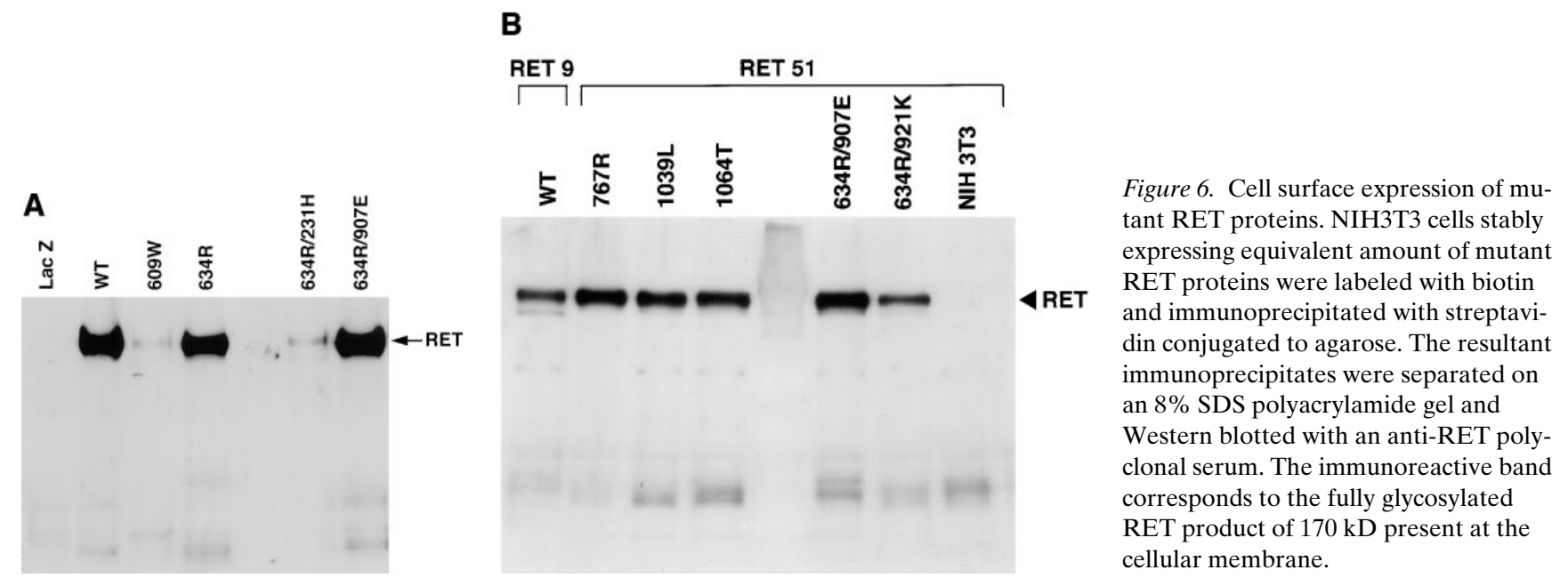




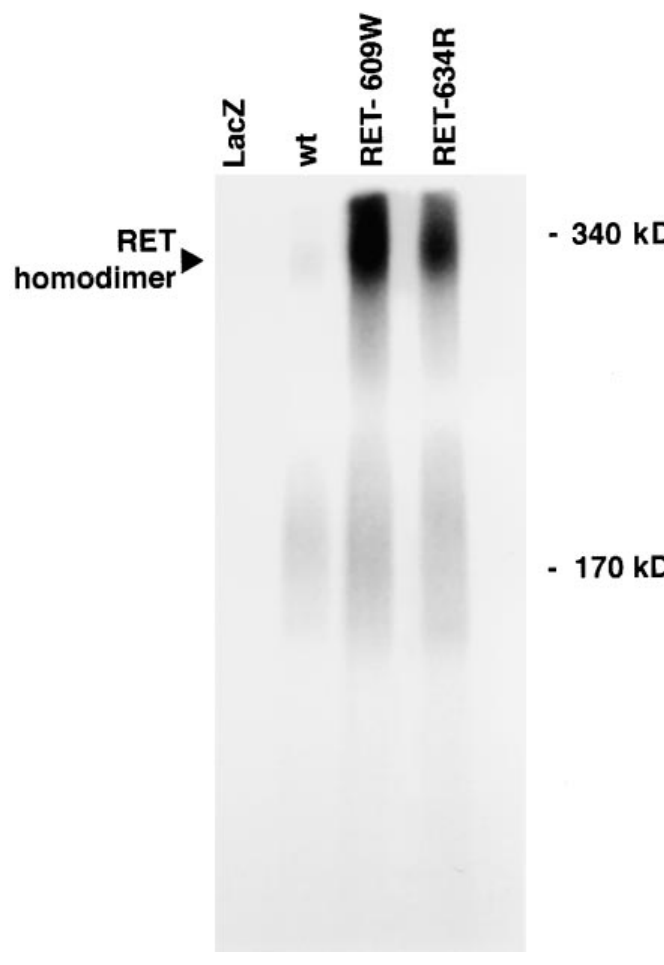

Figure 7. Dual effect of HSCR mutation C609W. Mutation C609W promotes RET covalent dimerization. NIH3T3 cells stably expressing equivalent amount of mutant RET proteins were lysed and the RET receptor was immunoprecipitated and subjected to an in vitro immunokinase assay using $\left[\gamma^{-32} \mathrm{P}\right] \mathrm{ATP}$. The immunoprecipitates were separated on an $8 \%$ SDS polyacrylamide gel under nonreducing conditions. The $340-\mathrm{kD}$ labeled product corresponds to the disulfide-linked RET homodimer.

from an unaffected parent (24). These mutations have not been identified in 100 control chromosomes and it seems unlikely that they are rare polymorphisms, although this possibility cannot be completely ruled out. However, it is possible that these mutations can reduce the activation of RET in response to GDNF, a hypothesis that should be tested in cells that stably express the RET coreceptor GDNFR $\alpha$ (data not shown). It is also possible that the signaling pathways activated from RET in enteric neurons depend on an array of transduction effectors which might not be expressed in fibroblasts or PC12 cells, while these mutations would indeed interfere with the ability of RET to mediate either the GDNF or the neurturin signal. Our data emphasize the necessity to develop fibroblast and/or neuronal cell cultures expressing RET coreceptors (GDNFR $\alpha$ and/or GDNFR $\beta$ ) providing better insights into the consequences of these mutations on RET function.

Hitherto, the biochemical and biological effects of 16 HSCR missense mutations affecting the RET protein have now been reported in four independent studies, including the present work (25-27). A survey of these results allow us to draw several conclusions: $(a)$ the vast majority of HSCR missense mutations (12/16) result in RET inactivation, therefore implying that HSCR can be merely ascribed to the loss of RET function or a reduced dosage of RET protein; $(b)$ however, rare HSCR-causing mutations could be activating (e.g., C609W); and $(c)$ the molecular mechanisms of RET dysfunction highly depend on the location of the mutation in the protein. We then propose to classify HSCR missense mutations of RET into four groups. Class I mutations are located in the extracytoplasmic domain, causing impairment in RET maturation and preventing the protein from reaching the cell surface. Class II mutations in the cysteine-rich domain might be responsible for both the formation of covalently linked RET dimers and the transport defect of the protein. Class III mutations are located in the tyrosine kinase domain altering either the catalytic activity or the stability of the enzyme structure. Finally, class IV mutations are found in the intracytoplasmic domain and might prevent the interaction between RET and cytosolic proteins which would be critical to signaling events. However, the absence of correlation between the nature or the position of the RET mutations and the clinical phenotype as well as the low penetrance of the disease indicates that other genetic factors might contribute to the HSCR phenotype. The recent demonstration that germline mutations in the gene encoding GDNF might either be responsible for or modify the HSCR clinical manifestations strengthens the view that the role of the multicomponent RET/GDNFR- $\alpha$ receptor is crucial during enteric neurogenesis (48-50). The identification of such components of the RET-signaling pathways should extend our understanding of the molecular bases of HSCR.

Note added in proof: Since the submission of this manuscript, Takahashi and co-workers reported on the biochemical analysis of the C609W mutation with results paralleling our data regarding $\mathrm{C} 609 \mathrm{~W}$ HSCR mutation (51).

\section{Acknowledgments}

We thank Dr. W.S. Pear for providing us with the BOSC 23 cells and Dr. H. Land for the pBabe Puro retroviral vector. We wish to thank L. Fournier for her excellent technical help, Mrs. M. Billaud and S. Balter for the graphic work, and S. Lefebvre, J. Amiel, and R. Salomon for helpful discussion.

This study was supported by the Ligue Nationale Contre le Cancer (Axe Oncogénèse and Comité Départemental de Saône et Loire), the Association de la Recherche sur le Cancer (ARC), the Association Française contre la Myopathie (AFM), the Assistance PubliqueHopitaux de Paris (AP-HP, PHRC94), and the Ministère de la Recherche (ACC-SV2). During this study, O. Geneste was the recipient of a Fellowship from the Ligue Nationale Contre le Cancer, Comité Départemental de l'Indre. S. Chappuis and A. Pasini are the recipients of a fellowship from the Association de Recherche sur le Cancer and from the Ligue Nationale contre le Cancer, respectively.

\section{References}

1. Hirschsprung, H. 1888. Stuhlträgheit neugeborener infolge von dilatation und hypertrophic des colons. Jb. Kinderheilk. 27:1.

2. Bolande, R. 1973. The neurocristopathies: a unifying concept of disease arising in neural crest maldevelopment. Hum. Pathol. 5:409-429.

3. Douarin, L. 1982. The Neural Crest. Cambridge University Press, Cambridge, United Kingdom.

4. Badner, J., W. Sieber, K. Garver, and A. Chakravarti. 1990. A genetic study of Hirschsprung disease. Am. J. Hum. Genet. 46:568-580.

5. Lyonnet, S., A. Bolino, A. Pelet, L. Abel, C. Nihoul-Fékété, M. Briard, V. Mok Siu, H. Kääriäinen, G. Martucciello, M. Lerone, et al. 1993. A gene for Hirschsprung disease maps to the proximal long arm of chromosome 10. Nat. Genet. 4:346-350.

6. Angrist, M., E. Kauffman, S.A. Slaugenhaupt, M. Cox Matise, E.G. Puffenberger, S.S. Washington, A. Lipson, D.T. Cass, T. Reyna, D.E. Weeks, et al. 1993. A gene for Hirschsprung disease (megacolon) in the pericentromeric region of human chromosome 10. Nat. Genet. 4:351-356.

7. Edery, P., S. Lyonnet, L. Mulligan, A. Pelet, E. Dow, L. Abel, S. Holder, C. Nihoul-Fekete, B. Ponder, and A. Munnich. 1994. Mutations of the RET 
proto-oncogene in Hirschsprung's disease. Nature. 367:378-380.

8. Romeo, G., P. Ronchetto, Y. Luo, V. Barone, M. Seri, I. Ceccherini, B. Pasini, R. Bocciardi, M. Lerone, H. Kääriäinen, et al. 1994. Point mutations affecting the tyrosine kinase domain of the RET proto-oncogene in Hirschsprung's disease. Nature. 367:377-378.

9. Takahashi, M., Y. Buma, T. Iwamoto, Y. Inaguma, and H. Ikeda. 1988. Cloning and expression of the ret proto-oncogene encoding a tyrosine kinase with two potential transmembrane domains. Oncogene. 3:571-578.

10. Durbec, P., C. Marcos-Gutierrez, C. Kilkenny, M. Grigoriou, K. Wartiowaara, P. Suvanto, P. Smith, B. Ponder, F. Costantini, M. Saarma, et al. 1996. Glial cell line-derived neurotrophic factor signaling through the Ret receptor tyrosine kinase. Nature. 381:789-793.

11. Jing, S., S. Jing, D. Wen, Y. Yu, P.L. Holst, Y. Luo, M. Fang, R. Tamir, L. Antonio, Z. Hu, et al. 1996. GDNF-induced activation of the Ret protein tyrosine kinase is mediated by GDNFR- $\alpha$, a novel receptor for GDNF. Cell. 85: 1113-1124.

12. Treanor, J.J., L. Goodman, F. de Sauvage, D.M. Stone, K.T. Poulsen, C.D. Beck, C. Gray, M.P. Armanini, R.A. Pollock, F. Hefti, et al. 1996. Characterization of a multicomponent receptor for GDNF. Nature. 382:80-83.

13. Trupp, M., E. Arenas, M. Fainziiber, A. Nilsson, B. Sieber, M. Grigoriou, C. Kilkenny, E. Salazar-Grueso, V. Pachnis, U. Arumäes, et al. 1996. Functional receptor for GDNF encoded by the c-ret proto-oncogene. Nature. 381:785-789.

14. Kotzbauer, P.T., P. Alampe, R.O. Heuckeroth, J.P. Golden, D.J. Credon, E.M. Johnson, Jr., and J. Milbrandt. 1996. Neurturin, a relative of glialcell-line neurotrophic factor. Nature. 384:467-470.

15. Baloh, R.H., M.G. Tansey, J.P. Golden, D.J. Credon, R.O. Heuckeroth, C.L. Keck, D.B. Zimonjic, N.C. Popescu, E.M. Johnson, Jr., and J. Milbrandt. 1997. TrnR2, a novel receptor that mediates nurturin and GDNF signaling through RET. Neuron. 18:793-802.

16. Goodfellow, P. 1994. Inherited cancers associated with the RET protooncogene. Curr. Opin. Genet. Dev. 4:446-452.

17. Mulligan, L.M., and B.A. Ponder. 1995. Genetic basis of endocrine disease: multiple endocrine neoplasia type 2. J. Clin. Endocrinol. Metab. 80:19891995.

18. Pasini, B., I. Ceccherini, and G. Romeo. 1996. RET mutations in human disease. Trends Genet. 12:138-144.

19. Eng, C., D. Clayton, I. Schuffenecker, G. Lenoir, G. Cote, R.F. Gagel, H.K. Van Amstel, C.J. Lips, I. Nishisho, S.I. Takai, et al. 1996. The relationship between specific RET proto-oncogene mutations and disease phenotype in multiple endocrine neoplasia type 2 . International RET mutation consortium analysis. JAMA (J. Am. Med. Assoc.). 276:1575-1579.

20. Santoro, M., F. Carlomagno, A. Romano, D.P. Bottaro, N.A. Dathan, M. Grieco, A. Fusco, G. Vecchio, B. Matoskova, M.H. Kraus, and P.P. Di Fiore. 1995. Activation of RET as a dominant transforming gene by germline mutations of MEN 2A and MEN 2B. Science. 267:381-383.

21. Asai, N., T. Iwashita, M. Matsuyama, and M. Takahashi. 1995. Mechanism of activation of the ret proto-oncogene by endocrine neoplasia $2 \mathrm{~A}$ mutations. Mol. Cell. Biol. 15:1613-1619.

22. Borrello, M.G., D.P. Smith, B. Pasini, I. Bongarzone, A. Greco, M.J. Lorenzo, E. Arighi, C. Miranda, C. Eng, L. Alberti, et al. 1995. RET activation by germline MEN2A and MEN2B mutations. Oncogene. 11:2419-2427.

23. Rossel, M., A. Pasini, S. Chappuis, O. Geneste, L. Fournier, I. Schuffenecker, M. Takahashi, L.A. Van Grunsven, J.L. Urdiales, B.B. Rudkin, et al. 1997. Distinct biological properties of two RET isoforms activated by MEN 2A and MEN 2B mutations. Oncogene. 14:265-275.

24. Attié, T., A. Pelet, P. Edery, C. Eng, L. Mulligan, J. Amiel, S. Beldjord, C. Nihoul-Fékété, A. Munnich, B. Ponder, and S. Lyonnet. 1995. Diversity of RET proto-oncogene mutations in Hirschsprung's disease. Hum. Mol. Genet. 4: 2407-2409.

25. Pasini, B., M.G. Borello, A. Greco, I. Bongarzone, Y. Luo, P. Mondellini, L. Alberti, C. Miranda, E. Arighi, R. Bocciardi, et al. 1995. Loss of function effect of RET mutations causing Hirschsprung disease. Nat. Genet. 10:35-40.

26. Carlomagno, F., G. De Vita, M.T. Berlingieri, V. De Franciscis, R.M. Mellilo, V. Colantuoni, M.H. Kraus, P.P. Di Fiore, A. Fusco, and M. Santoro. 1996. Molecular heterogeneity of RET loss of function in Hirschsprung's disease. EMBO (Eur. Mol. Biol. Organ.) J. 15:2717-2725.

27. Iwashita, T., H. Murakami, N. Asai, and M. Takahashi. 1996. Mechanism of Ret dysfunction by Hirschsprung mutations affecting its extra cellular domain. Hum. Mol. Genet. 5:1578-1580.

28. Schuchardt, A., V. D’Agati, L. Larsson-Blomberg, F. Costantini, and V. Pachnis. 1994. Defects in the kidney and enteric nervous system of mice lacking the tyrosine kinase receptor Ret. Nature. 367:380-383.

29. Mulligan, L.M., C. Eng, T. Attie, S. Lyonnet, D.J. Marsh, V.J. Hyland, B.G. Robinson, A. Frilling, C. Verellen-Dumoulin, A. Safar, et al. 1994. Di- verse phenotypes associated with exon 10 mutations of the RET proto-oncogene. Hum. Mol. Genet. 3:2163-2167.

30. Morgenstern, J.P., and H. Land. 1990. Advanced mammalian gene transfer: high titre retroviral vectors with multiple drug selection markers and a complementary helper-free packaging cell line. Nucleic Acids Res. 18:35873596.

31. Pear, W.S., G.P. Nolan, M.L. Scott, and D. Baltimore. 1993. Production of high-titer helper-free retroviruses by transient transfection. Proc. Natl. Acad. Sci. USA. 90:8392-8396.

32. D'Arcangelo, G., and S. Halegoua. 1993. A branched signaling pathway for nerve growth factor is revealed by Src-, Ras-, and Raf-mediated gene inductions. Mol. Cell. Biol. 13:3146-3155.

33. Taniguchi, M.I.T., M. Hamaguchi, M. Matsuyama, and M. Takahashi. 1991. The RET oncogene products are membrane-bound glycoproteins phosphorylated on tyrosine residues in vivo. Biochem. Biophys. Res. Commun. 181: 416-422.

34. Bonfini, L.M.E., G. Pelicci, L. Lanfrancone, and P.G. Pelicci. 1996. Not all Shc's roads lead to Ras. Trends Biochem. Sci. 21:257-261.

35. Asai, N., H. Murakami, T. Iwashita, and M. Takahashi. 1996. A mutation at tyrosine 1062 in MEN2A-RET and MEN2B-RET impairs their transforming activity and association with Shc adaptor proteins. J. Biol. Chem. 271: 17644-17649.

36. Arighi, E., L. Alberti, F. Torriti, S. Ghizzoni, M.G. Rizzetti, G. Pelici, B Pasini, C. Bongarzone, C. Piutti, M.A. Pierotti, and M.G. Borrello. 1997. Identification of Shc docking site on Ret tyrosine kinase. Oncogene. 14:773-782.

37. Lorenzo, M.J., G.D. Gish, C. Houghton, T.J. Stonehouse, T. Pawson, B.A.J. Ponder, and D.P. Smith. 1997. RET alternate splicing influences the interaction of activated RET with the $\mathrm{SH} 2$ and PTB domains of Shc, and the $\mathrm{SH} 2$ domain of Grb2. Oncogene. 14:763-771.

38. Shapiro, L.F.A., P.D. Kwong, A. Thompson, M.S. Lehmann, L.J. Grubel, J. Als-Nielsen, D.R. Colman, and W.A. Hendrickson. 1995. Structural basis of cell-cell adhesion by cadherins. Nature. 374:327-337.

39. Nagar, B.O.M., M. Ikura, and J.M. Rini. 1996. Structural basis of calcium-induced E-cadherin rigidification and dimerization. Nature. 380:360-364.

40. Takahashi, M., N. Asai, T. Iwashita, T. Isomura, K. Miyazaki, and M. Matsuyama. 1993. Characterization of the ret proto-oncogene products expressed in mouse L cells. Oncogene. 8:2925-2929.

41. Iwashita, T., N. Asai, H. Murakami, M. Matsuyama, and M. Takahashi. 1996. Identification of tyrosine residues that are essential for transforming activity of the ret proto-oncogene with MEN2A or MEN2B mutation. Oncogene. 12:481-487.

42. Pandey, A., H. Duan, P.P. Di Fiore, and V.M. Dixit. 1995. The Ret receptor protein tyrosine kinase associates with the $\mathrm{SH} 2$-containing adapter protein Grb10. J. Biol. Chem. 270:21461-21463.

43. Pandey, A., X. Liu, J.E. Dixon, P.P. Di Fiore, and V.M. Dixit. 1996. Direct association between the Ret receptor tyrosine kinase and the Src homology 2-containing adapter protein Grb7. J. Biol. Chem. 271:10607-10610.

44. Durick, K., R.Y. Wu, G.N. Gill, and S.S. Taylor. 1996. Mitogenic signaling by Ret/ptc2 requires association with enigma via a LIM domain. J. Biol. Chem. 271:12691-12694.

45. Hanks, S.K., A. Quinn, and T. Hunter. 1988. The protein kinase family: conserved features and deduced phylogeny of the catalytic domains. Science. 241:42-52.

46. Angrist, M., S. Bolk, B. Thiel, E. Puffenberger, R. Hofstra, C. Buys, and A. Chakravarti. 1995. Mutation analysis of the RET receptor tyrosine kinase in Hirschsprung disease. Hum. Mol. Genet. 4:821-830.

47. Carlomagno, F., G. Salvatore, A.M. Cirafici, G. De Vita, R.M. Melillo, V. De Franciscis, M. Billaud, A. Fusco, and M. Santoro. 1997. The differen RET-activating capability of mutations of cysteine 620 or cysteine 634 correlates with the multiple endocrine neoplasia type 2 disease phenotype. Cancer Res. 57:391-395.

48. Salomon, R., T. Attie, A. Pelet, C. Bidaud, C. Eng, J. Amiel, S. Sarnacki, O. Goulet, C. Ricour, C. Nihoul-Fekete, et al. 1996. Germline mutations of the RET ligand, GDNF, are not sufficient to cause Hirschsprung disease. Nat. Genet. 14:345-347.

49. Angrist, M., S. Bolk, M. Halushka, P.A. Lapchak, and A. Chakravarti. 1996. Germline mutations in glial cell line-derived neurotrophic factor (GDNF) and RET in a Hirschsprung disease patient. Nat. Genet. 14:341-343.

50. Ivanchuk, S.M., S.M. Myers, C. Eng, and L.M. Mulligan. 1996. De novo mutation of GDNF, ligand for the RET/GDNFR-a receptor complex, in Hirschsprung disease. Hum. Mol. Genet. 5:2023-2026.

51. Ito, S., T. Iwashita, N. Asai, H. Murakami, Y. Iwata, G. Sobue, and M. Takahashi. 1997. Biological properties of Ret with cysteine mutations correlate with multiple endocrine neoplasia type $2 \mathrm{~A}$, familial medullary thyroid carcinoma, and Hirschsprung's disease phenotype. Cancer Res. 57:2870-2872. 